\title{
A theoretically based cross-sectional survey on the behaviors and experiences of clinical pharmacists caring for patients with chronic kidney disease
}

\author{
F. Alraiisi ${ }^{\text {a }}$, D. Stewart ${ }^{\mathrm{b}}$, C. Ashley ${ }^{\mathrm{c}}$, M. Fahmy ${ }^{\mathrm{d}}$, H. Alnaamani ${ }^{\mathrm{e}}$, S. Cunningham ${ }^{\mathrm{a},{ }^{*}}$ \\ ${ }^{a}$ School of Pharmacy and Life Sciences, Robert Gordon University, Aberdeen, AB10 7GJ, UK \\ ${ }^{\mathrm{b}}$ College of Pharmacy, QU Health, Qatar University, Doha, PO Box 2713, Qatar \\ ${ }^{c}$ Royal Free Hampstead NHS Trust, Pond St, Hampstead, London, NW3 2QG, UK \\ d Oman College of Health Sciences, P.O Box 1928, 114, Muttrah, Oman \\ ${ }^{\text {e }}$ Royal Hospital, P.O Box 1331, 111, Alseeb, Oman
}

\section{A R T I C L E I N F O}

\section{Keywords:}

Chronic kidney disease

Clinical pharmacist

Survey

Behaviors and experiences

\begin{abstract}
A B S T R A C T
The literature shows a lack of evidence on pharmacists contributing to chronic kidney disease services. The aim was to determine pharmacists' behaviors and experiences and perceptions of barriers and facilitators to implementation of models of care.

A theoretically informed survey was developed and sent to pharmacist members of the United Kingdom renal pharmacy group. Sections included: demographics, clinical practice and prescribing practice. Questions were of various types; closed type and some open for comments. Attitudinal items on clinical/prescribing used 5-point Likert scale. Development/implementation items were derived from the Consolidated Framework for Implementation Research (CFIR). Analysis used descriptive statistics and open comments were analysed thematically. Ethical approval was granted by an academic institution.

Response rate; $50 \%(n=71)$, seven were incomplete and excluded. Respondents provided; inpatient general pharmaceutical care $(n=56,87.5 \%)$, to those receiving dialysis $(n=54,84.4 \%)$ and transplantation. Nonclinical roles; audits $(n=46,71.9 \%)$, patient education $(n=31,48.4 \%)$, only $7.8 \%(n=5)$ doing academic research. For barrier/facilitators most strongly agreed/agreed with most CFIR items relating to clinical practice. A majority $(n=44,68.7 \%)$ disagreed that they had sufficient time to practice clinically and $44(68.7 \%)$ disagreed there was sufficient cover for services. For prescribing roles, $90.5 \%(n=48)$ were currently actively prescribing. Although prescribing related CFIR items were largely positive, $39.6 \%(\mathrm{n}=19)$ disagreed about sufficient time to practice and $18.7 \%(n=9)$ were neutral. Two thirds $(n=33,68.7 \%)$ disagreed that there was sufficient cover for the prescribing.

The majority of respondents provided general pharmaceutical care to dialysis and transplant patients, were confident in their abilities and tried new ways of working including independent prescribing. Many expressed that lack of resources was the main barrier to providing more advanced care. Further work is needed to explore these matters in more depth.
\end{abstract}

\section{Introduction}

Chronic kidney disease (CKD) is defined as 'progressive abnormalities of kidney structure and/or function over a period of time varying from weeks to months, with implications for health'. ${ }^{1}$ A recent systematic review and meta-analysis reported that the global prevalence of
CKD, with a rate between $11 \%$ and $13 \%$, is high compared to other diseases. ${ }^{2}$ The Kidney Disease Outcome Quality Initiative has classified the stages of CKD with linked action plans (Table 1 ). ${ }^{3}$

CKD is a complex comorbid condition with; high economic burden, reduced quality of life, frequent hospitalization, reduced life expectancy and high risk of mortality. ${ }^{1,2,4,5}$ Patients are prescribed an array of

\footnotetext{
* Corresponding author.

E-mail addresses: f.a.a.al-raiisi@rgu.ac.uk (F. Alraiisi), d.stewart@qu.edu.qa (D. Stewart), carolineashley@nhs.net (C. Ashley), mmsakreem59@hotmail.com (M. Fahmy), halnaamani@hotmail.com (H. Alnaamani), s.cunningham@rgu.ac.uk (S. Cunningham).
} 
Table 1

Stages of CKD: A clinical action plan.

\begin{tabular}{|c|c|c|c|}
\hline stage & Description & $\begin{array}{l}\text { Glomerular } \\
\text { Filtration Rate } \\
\text { (GFR) } \\
(\mathrm{ml} / \mathrm{min} / \\
\left.1.73 \mathrm{~m}^{2}\right)\end{array}$ & Action \\
\hline 1 & $\begin{array}{l}\text { Kidney damage } \\
\text { with normal or } \uparrow \\
\text { GFR }\end{array}$ & $\geq 90$ & $\begin{array}{l}\text { Diagnosis and treatment, } \\
\text { treatment of comorbid } \\
\text { conditions, slowing progression, } \\
\text { cardiovascular disease (CVD) } \\
\text { risk reduction }\end{array}$ \\
\hline 2 & $\begin{array}{l}\text { Kidney damage } \\
\text { with mild } \downarrow \text { GFR }\end{array}$ & $60-89$ & Estimating progression \\
\hline 3 & Moderate $\downarrow$ GFR & $30-59$ & $\begin{array}{l}\text { Evaluating and treating } \\
\text { complications }\end{array}$ \\
\hline 4 & Severe $\downarrow$ GFR & $15-29$ & $\begin{array}{l}\text { Preparation for kidney } \\
\text { replacement therapy }\end{array}$ \\
\hline 5 & Kidney failure & $<15$ & Replacement (if uremia present) \\
\hline
\end{tabular}

CKD is defined as either kidney damage or GFR $<60 \mathrm{ml} / \mathrm{min} / 1.73 \mathrm{~m}^{2}$ for $\geq 3$ months. Kidney damage is defined as pathological abnormalities or markers of damage, including abnormalities in blood or urine tests or imaging studies. Adapted from Levey et al. ${ }^{3}$

medications which can result in medication burden, potential for reduced adherence and increased adverse effects. ${ }^{6}$ In view of this, there is significant opportunity for pharmacists to contribute to the multidisciplinary care of CKD patients and so improve patient outcomes. ${ }^{7}$ A systematic review ${ }^{9}$, published in 2012 , included 37 peer-reviewed papers and aimed to assess the impact of pharmacists' interventions on the management of patients with CKD. It reported that through the systematic provision of pharmaceutical care (i.e. person-focused care relating to medication with the aim of improving the outcomes of therapy and provided by a pharmacist and the pharmacy team ${ }^{8}$ ) pharmacists have the potential to contribute significantly to the multidisciplinary team leading safe, effective and economic care for patients. ${ }^{9} \mathrm{~A}$ subsequent systematic review in 2019 aimed to critically appraise, synthesise and present the available evidence for the structures, processes and related outcomes of clinical pharmacy practice (i.e. pharmacists direct contribution to patient care and the development and promotion of the rational use of medication at any level of healthcare practice) as part of the multidisciplinary care of patients with CKD. ${ }^{10}$ The review included 47 studies and reported that there is limited evidence on the structures and processes of care for patients with CKD. The review also reported some evidence for the outcomes of pharmacists' interventions in patients with CKD but these studies were generally of low quality and insufficient volume. Controlled studies in the review showed that pharmacist interventions improved patients' clinical outcomes such as hemoglobin concentration levels, creatinine clearance, parathyroid hormone and calcium levels. However, these studies lacked detail on reporting of the humanistic outcomes such as quality of life, patient satisfaction and functional status. The review also showed that there is also limited evidence demonstrating economic impact of pharmacists' interventions.

Of the studies identified, very few were of a 'gold standard' RCT design and the quality of other types of study with controls, that were included, was generally poor. ${ }^{9,10}$ RCTs lacked sufficient information on the randomisation and blinding processes so jeopardising the quality of these studies. Structures and processes were also very poorly reported with most papers lacking sufficient details of the clinical pharmacy practices. Without such information it is difficult to fully understand the context and characteristics of the models of practice so making transferability difficult. This lack of detail also greatly limits the potential to standardise data collection and pool data, particularly relating to outcomes. There were no studies that have specifically investigated prescribing as part of clinical pharmacy practice and there are no gold standard RCTs with full description of structure, processes and outcomes as they relate to prescribing practice.
Generally, uncontrolled studies had a variety of quality deficiencies including; lack of comprehensive explanation of the pharmacists' intervention, under-reporting of adverse events and insufficient information to allow reproduction of the studies.

A study by Yamamoto et al. showed a decline in hospital admissions from $71.4 \%$ to $38.1 \%(\mathrm{P}=0.03)$ after the pharmacists' intervention. ${ }^{12}$ Another study included 204 patients reported that there was; a reduction in the average cost of medication, better therapeutic drug monitoring of immunosuppressive drugs within target levels and higher blood pressure control in the post-intervention group. ${ }^{13} \mathrm{~A}$ further recent example of the limited evidence in this area is a subgroup analysis of a randomized controlled trial that evaluated the effect of a community pharmacy-based intervention on estimation of cardiovascular (CV) risk in patients with CKD. This study showed that pharmacist-led care of patients with CKD reduced CV risk and improved control of CV risk factors. ${ }^{14}$ These studies highlight that the inclusion of pharmacists in a multidisciplinary team can improve patient outcomes. However, what is not clear from these studies, is the detail of the structures and processes required to achieve these outcomes.

A major limitation of the evidence base to date is that few studies have used implementation theory for any part of the research process. It is increasingly recognised that underpinning research with suitable theoretical frameworks is essential. A range of frameworks have been developed by researchers and selecting the most suitable framework depends on the aim and type of research. An example is the Consolidated Framework for Implementation Research (CFIR) which consists of a menu of constructs that have been associated with effective implementation. It was developed from a review of 500 published sources across 13 scientific disciplines and a range of other sources. It can be used to assess potential barriers and facilitators in preparation for implementing of an innovation. The use of theory throughout the research process can provide a more comprehensive and consistent approach to consider all factors associated with the research. ${ }^{11}$

The UK Renal Pharmacy Group (UKRPG - www.renalpharmacy.org. uk) is a professional group that aims to support the development of pharmacists in the care of patients with CKD and to standardise structures and processes for practice. The group has developed a competency framework for pharmacists providing care to renal patients including those with CKD. This describes a broad range of clinical activities that can be provided and helps define general aspects of practice to support pharmacists in their career progression through advanced to the consultant-level renal clinical pharmacy practice. ${ }^{15}$ Despite the range of activities captured in the framework Al Raiisi et al. ${ }^{10}$ have shown that there is a paucity of quality research that clearly characterizes the structures and processes of this broad range of services related to care provision.

Pharmacists can qualify as independent nonmedical prescribers in the UK and this permits them to prescribe, within their competence, the same range of medications as physicians. ${ }^{16,17}$ Prescribing models have also been implemented or trialled in several other countries such as; Canada, New Zealand, Australia and some states of the USA. ${ }^{17,18}$ While there is expanding recognition for the support of nonmedical prescribing at policy making levels ${ }^{17,18}$ there still remains limited information relating to the detail of the models of nonmedical prescribing practice and this particularly true within the care of patients with CKD.

There is therefore a need for more robust and rigorous research to describe and characterise fully the contribution of pharmacists. The aim of this study was to determine pharmacists' behaviors and experiences and the barriers and facilitators to the implementation of models of care in patients with CKD.

\section{Method}

Research design

This study was a cross-sectional survey using an online 
questionnaire.

Setting

The research was conducted in the UK using the membership of the UKRPG as the sampling frame. UKRPG is a not-for-profit organization established in the early 1980s and currently has in excess of 200 clinical and administrative members. The group includes pharmacists from across the UK and a few international members either practicing renal pharmacy or have interest in renal medicine.

\section{Participants}

\section{Inclusion and exclusion criteria}

All pharmacists who are members of the UKRPG were invited to participate.

Exclusion was for pharmacists not practicing clinically in the UK.

\section{Questionnaire development}

The development of the questionnaire tool followed an iterative process based on a comprehensive literature search including relevant electronic databases (PubMed, International Pharmaceutical Abstracts (IPA), Cumulative Index to Nursing and Allied Health Literature (CINAHL), and Scopus). This was in addition to the summary of research related to the topic identified from a recent systematic review conducted by the research team. ${ }^{10}$ This enabled the identification of key concepts and themes to be included in the draft questionnaire. Face and content validity testing were carried out by six expert researchers from an academic institution and pharmacist practitioners from secondary care. 'Think aloud' testing was carried out with three clinical pharmacists not involved in any other process of the questionnaire development. The final version of the questionnaire was developed in 'Online Surveys', JISC, UK (formerly Bristol Online Survey Tool ${ }^{\circledR}$, https://www.jisc.ac. uk/online-surveys), and piloted with a random sample of 14 (around $10 \%$ of the target population) members of the UKRPG. Piloting resulted in only minor formatting changes, so pilot data were included in the final dataset.

At the outset of the questionnaire, an initial screening question identified those UKRPG members not practicing clinical pharmacy in the UK. Remaining items were grouped into sections of: demographics, clinical practice (characteristics and types of clinical pharmacy services provided for outpatients and inpatients) and prescribing practice (development and implementation of prescribing practice, model of prescribing, areas and frequency of prescribing). Questionnaire items were of various types including, where appropriate, closed type questions and some open questions to allow respondents to provide explanatory comments. Attitudinal type items on the development of clinical and prescribing practice used a 5-point Likert scale format. In the demographics section of the questionnaire, participants were asked to respond to a question relating to descriptors from Rogers Diffusion of Innovation theory these included whether they felt they were; 'laggards', 'late majority', 'early majority', 'early adopters' or 'innovators'. ${ }^{19}$

Items on development and implementation of clinical and prescribing practice were derived from the Consolidated Framework for Implementation Research (CFIR), which is based on the principles of implementation theory. ${ }^{11}$ CFIR includes five major domains (intervention characteristics: aspects on the intervention that may impact the implementation success, outer setting: external influences on intervention implementation, inner setting: characteristics of the implementing organization, characteristics of individuals: individuals attributes and belief towards the intervention and process: stages of implementation) with 39 underlying constructs and sub-constructs that can potentially influence efforts to change practice. ${ }^{11,20}$ The most relevant constructs were used to guide the development of the survey questions to ensure comprehensive coverage of the most important elements of the clinical and prescribing practice of pharmacists in the care of patients with CKD.

\section{Data collection}

An invitation email, with a link to the questionnaire and the participant information leaflet, was sent to the UKRPG coordinator to distribute to members. Evidence-based approaches were used to enhance the response rate, ${ }^{21}$ namely an information leaflet to outline study objectives and potential benefits, entry into a prize draw, and two reminders at monthly intervals. In addition, the lead researcher promoted the work at the annual UKRPG conference and encouraged the pharmacists to participant in the survey.

Data were collected over a period of six weeks from $17^{\text {th }}$ of September 2018 till $28^{\text {th }}$ of October 2018.

\section{Data analysis}

Data were analysed using descriptive statistics using Statistical Package for the Social Sciences SPSS ${ }^{\circledR}$ Statistics Version 25; the population size and number of respondents limited the potential for inferential analysis. Free text comments were analysed independently by two researchers by using the Framework Approach to qualitative data content analysis. ${ }^{22}$

\section{Ethical considerations}

The Ethical Review Panel of the School of Pharmacy and Life Sciences at Robert Gordon University, UK approved this study (S130). As the study recruited members of a professional network, formal National Health Service approval was not required.

\section{Results}

Seventy-one responses were received from the 142 participants invited to take part giving a response rate of $50 \%$. Of the 71 responses, seven were not currently practicing clinical pharmacy giving 64 responses for analysis.

Table 2 summarizes demographics of the study participants. Almost three quarter were female $(78.1 \%, \mathrm{n}=50)$ with just over half being $31-40$ years of age $(51.6 \%, n=33)$. All were mainly practicing in secondary care setting as their main job sector $(100 \%, n=64)$, with ( $45.3 \%, n=29)$ participants had experience of working in community pharmacy and very few in general practice $(3.1 \%, \mathrm{n}=2)$ A majority of the respondents were practicing in England $(75 \%, \mathrm{n}=48)$. Over a third $(35.9 \%, n=23)$ of the pharmacists have been providing care for patients with CKD for $1-5$ years with $20.3 \%(n=13)$ for $11-15$ years and fiftythree $(82.8 \%, \mathrm{n}=53)$ of respondents were non-medical prescribers. More than half of respondents $(57.8 \%, \mathrm{n}=37)$ indicated that they 'think for some time before adopting new ways of working' which corresponds with the 'early majority' category in Rogers Diffusion of Innovation. ${ }^{19}$

Full data from the survey is provided in Tables $3-5$ with key findings from each highlighted below.

\section{Clinical pharmacy services for inpatients}

All the respondents were providing care in the inpatient setting $(\mathrm{n}=$ $64)$ in a variety of areas as shown in Table 3 . The majority of respondents $(87.5 \%, \mathrm{n}=56)$ provided general pharmaceutical care, with pharmaceutical care specifically for dialysis patients provided by $84.4 \%(\mathrm{n}=$ 54). Individual patient medication related education was provided by $85.9 \%(n=55)$, while $81.3 \%(n=52)$ of the respondents had regular meetings with the multidisciplinary team.

Pharmaceutical care for transplantation patients was provided by $71.9 \%(n=46)$ of the respondents with such services provided with a variety of frequencies but by more than half $(54.3 \%, \mathrm{n}=25)$ on a daily 
Table 2

Demographic characteristics $(\mathrm{N}=64)$.

\begin{tabular}{|c|c|c|}
\hline Title & Categories & n (\%) \\
\hline \multirow[t]{2}{*}{ Gender } & Male & $14(21.9)$ \\
\hline & Female & $50(78.1)$ \\
\hline \multirow[t]{5}{*}{ Age } & Less than 30 years & 14 (21.9) \\
\hline & $31-40$ years & $33(51.6)$ \\
\hline & $41-50$ years & $10(15.6)$ \\
\hline & $51-60$ years & 7 (10.9) \\
\hline & 61 year and above & $0(0)$ \\
\hline \multirow[t]{5}{*}{ Main job sector of practice } & Secondary care & $64(100)$ \\
\hline & Primary care & $0(0)$ \\
\hline & GP practice & $0(0)$ \\
\hline & Community pharmacy & $0(0)$ \\
\hline & Other & $0(0)$ \\
\hline \multirow{4}{*}{$\begin{array}{l}\text { Geographical area of } \\
\text { practice }\end{array}$} & England & $48(75)$ \\
\hline & Scotland & $10(15.6)$ \\
\hline & Wales & $4(6.3)$ \\
\hline & Northern Ireland & $2(3.1)$ \\
\hline \multirow{7}{*}{$\begin{array}{l}\text { Academic qualifications } \\
\text { (Multiple selection } \\
\text { allowed) }\end{array}$} & BSc & $16(10.2)$ \\
\hline & MPharm & $46(29.3)$ \\
\hline & Postgraduate diploma & $49(31.2)$ \\
\hline & Postgraduate certificate & $11(7)$ \\
\hline & MSc & $16(10.2)$ \\
\hline & $\mathrm{PhD}$ & $3(1.9)$ \\
\hline & Other & $16(10.2)$ \\
\hline \multirow{7}{*}{$\begin{array}{l}\text { Years qualified as a } \\
\text { pharmacist }\end{array}$} & less than a year & $0(0)$ \\
\hline & $1-5$ years & $9(14.1)$ \\
\hline & $6-10$ years & $13(20.3)$ \\
\hline & $11-15$ years & $17(26.5)$ \\
\hline & $16-20$ years & $10(15.6)$ \\
\hline & More than 20 years & $14(21.9)$ \\
\hline & Missing & $1(1.6)$ \\
\hline \multirow{7}{*}{$\begin{array}{l}\text { Years worked in hospital } \\
\text { pharmacy }\end{array}$} & Never worked in this sector & $0(0)$ \\
\hline & Less than 1 year & $1(1.6)$ \\
\hline & $1-5$ years & $11(17.2)$ \\
\hline & $6-10$ years & $12(18.8)$ \\
\hline & 11-15years & $20(31.3)$ \\
\hline & $16-20$ years & $8(12.5)$ \\
\hline & more than 20 years & $12(18.8)$ \\
\hline \multirow[t]{8}{*}{$\begin{array}{l}\text { Years providing clinical care } \\
\text { for patients with CKD }\end{array}$} & less than a year & $\begin{array}{l}8 \\
(12.5 \%)\end{array}$ \\
\hline & $1-5$ years & 23 \\
\hline & & $(35.9 \%)$ \\
\hline & $6-10$ years & $\begin{array}{l}10 \\
(15.6 \%)\end{array}$ \\
\hline & 11-15 years & 13 \\
\hline & & $(20.3 \%)$ \\
\hline & 16-20 years & $5(7.8 \%)$ \\
\hline & More than 20 years & $5(7.8 \%)$ \\
\hline \multirow[t]{5}{*}{$\begin{array}{l}\text { Characteristics of the } \\
\text { innovation }\end{array}$} & $\begin{array}{l}\text { I resist new ways of working, I am } \\
\text { cautious in relation to new ways of } \\
\text { working (laggards) }\end{array}$ & $0(0)$ \\
\hline & $\begin{array}{l}\text { I tend to change once most of my peers } \\
\text { have done so (late majority) }\end{array}$ & $4(6.3)$ \\
\hline & $\begin{array}{l}\text { I think for some time before adopting } \\
\text { new ways of working (early majority) }\end{array}$ & $37(57.8)$ \\
\hline & $\begin{array}{l}\text { I serve as a role model for others in } \\
\text { relation to new ways of working (early } \\
\text { adopter) }\end{array}$ & $10(15.6)$ \\
\hline & $\begin{array}{l}\text { I am innovative with new ways of } \\
\text { working (innovators) }\end{array}$ & $13(20.3)$ \\
\hline \multirow[t]{2}{*}{ Nonmedical prescriber } & Yes & $53(82.8)$ \\
\hline & No & $11(17.2)$ \\
\hline
\end{tabular}

basis during the working week.

Medicines reconciliation was the most frequently provided service with $89.1 \%(n=57)$ of respondents indicating that this service was provided throughout the week (i.e. daily weekdays and daily weekdays and weekends) by $85.9 \%(n=49)$

Consulting inpatients with different CKD related conditions was performed by almost three-quarter of the participants, with $76.6 \%$ (n = 49) consulting patients with mineral bone disease, acute kidney injury by $76.6 \%(n=49)$, other renal complications by $71.9 \%(n=46)$ and consulting inpatients on hemodialysis or peritoneal dialysis by $70.3 \%$ (n $=45$ ). These consultations were provided mostly on daily basis on weekdays or on an 'ad hoc' basis by most of the participants in the inpatient setting.

Compared to the above there were 'Areas of care' where respondents indicated they were less involved. Around two thirds of respondents indicated that they attended medical ward rounds with the multidisciplinary team $(67.2 \%, \mathrm{n}=43)$ with a third of these $(37.2 \%, \mathrm{n}=16)$ indicating doing this on a daily basis during the working week. Targeted disease specific medication review services were also less developed with almost two thirds undertaking anemia targeted review $(65.6 \%, \mathrm{n}=$ $42)$, vasculitis by $68.8 \%(n=44)$ and hypertension by $65.6 \%(n=42)$.

\section{Clinical pharmacy services for outpatients}

The provision of care in the outpatient setting was generally less frequent than the inpatient setting. The characteristics of services in the outpatient setting are provided in Table 4 . The most frequently performed activities included; providing general pharmaceutical care by $62.5 \%(\mathrm{n}=40)$ and meeting with the multidisciplinary team by $64.1 \%$ $(n=41)$. General pharmaceutical care for patients in an outpatient setting was performed by $40 \%(n=16)$ of the respondents on a daily basis during weekdays, whereas, $32.5 \%(n=13)$ were providing the care on an 'ad hoc' basis.

Many of the respondents were providing pharmaceutical care for patients receiving dialysis $(59.4 \%, \mathrm{n}=38)$ and transplantation $(57.8 \%$, $\mathrm{n}=37$ ). These activities were provided daily on weekdays by $34.2 \%$ ( $=13)$ and $35.2 \%(n=13)$ respectively. Less frequently provided activities were; consulting for specific conditions including hemodialysis or peritoneal dialysis $(34.4 \%, \mathrm{n}=22)$, other renal complications $(31.3 \%, \mathrm{n}=20)$, acute kidney injury $(14.1 \%, \mathrm{n}=9)$ and mineral bone disease $(26.6 \%, \mathrm{n}=17)$ mostly on an ad hoc basis.

Individual patient medication related education was performed by $59.4 \%(n=38)$ of the respondents, mostly either on an 'ad hoc' basis by $42.1 \%(\mathrm{n}=16)$, 'two to three times a week' by $23.7 \%(\mathrm{n}=9)$ or 'once a week' by $21.1 \%(n=8)$ of the respondents. Targeted disease specific medication reviews were again among the least frequently performed activities in the outpatient setting with only a quarter undertaking hypertension reviews $(25 \%, \mathrm{n}=42), 34.4 \%$ doing vasculitis reviews ( $\mathrm{n}=$ $22)$, and $32.8 \%$ doing anemia reviews $(\mathrm{n}=21)$.

\section{Additional roles of pharmacists to support delivery of services}

Additional roles undertaken by the pharmacist to support delivery of patient care are shown in Table 5.

The most frequently performed additional roles were delivering education and training for other pharmacy staff $(90.6 \%$, $(n=58)$, other healthcare professionals $(84.4 \%, \mathrm{n}=54 / 64)$ and students $(81.3 \%, \mathrm{n}=$ $52)$. The least frequently performed activities were academic research $(7.8 \%, \mathrm{n}=5)$ and care home support $(9.4 \%, \mathrm{n}=6)$. A number of respondents were planning to perform these activities within the next 12 months, with a third $(34.4 \%, \mathrm{n}=22)$ of respondents planning to undertake academic research. Few $(3.1 \%, n=2)$, however, were planning to conduct care home support.

\section{Development and implementation of clinical pharmacy practice}

Table 6 provides responses to the statements on the development and implementation of clinical pharmacy practice in relation to CFIR domains and constructs.

Overall the respondents held positive views on the statements. However, of the 64 respondents the majority $(61 \%, n=39)$ agreed or strongly agreed on the need for more evidence around the benefits of 
Table 3

Characteristics of clinical pharmacy services you provide for INPATIENTS with CKD $(\mathrm{N}=64)$.

\begin{tabular}{|c|c|c|c|c|c|c|c|}
\hline \multirow[t]{3}{*}{ Area of care } & \multirow{3}{*}{$\begin{array}{l}\begin{array}{l}\text { Provision of } \\
\text { care }\end{array} \\
\text { Currently doing } \\
\mathrm{n}(\%)\end{array}$} & \multicolumn{6}{|c|}{ Frequency of 'currently doing' care provision } \\
\hline & & \multirow{2}{*}{$\begin{array}{l}\text { Daily } \\
\text { Weekdays } \\
\mathrm{n}(\%)\end{array}$} & \multirow{2}{*}{$\begin{array}{l}\text { Daily Weekdays and } \\
\text { Weekends } \\
\mathrm{n}(\%)\end{array}$} & \multirow{2}{*}{$\begin{array}{l}2-3 \mathrm{x} / \\
\text { week } \\
\mathrm{n}(\%)\end{array}$} & \multirow{2}{*}{$\begin{array}{l}\text { Once/ } \\
\text { week } \\
\mathrm{n}(\%)\end{array}$} & \multirow{2}{*}{$\begin{array}{l}\text { Ad hoc } \\
\mathrm{n}(\%)\end{array}$} & \multirow{2}{*}{$\begin{array}{l}\text { Missing } \\
\mathrm{n}(\%)\end{array}$} \\
\hline & & & & & & & \\
\hline General pharmaceutical care & $56(87.5)$ & $33(58.9)$ & $13(23.2)$ & $7(12.5)$ & $1(1.8)$ & $2(3.6)$ & $0(0)$ \\
\hline Pharmaceutical care for patients receiving dialysis & $54(84.4)$ & $32(59.3)$ & $8(14.8)$ & $6(11.1)$ & $2(3.7)$ & $6(11.1)$ & $0(0)$ \\
\hline $\begin{array}{l}\text { Pharmaceutical care for patients at transplantation/ } \\
\text { follow-up }\end{array}$ & $46(71.9)$ & $25(54.3)$ & $8(17.4)$ & $6(13)$ & $3(6.5)$ & $4(8.7)$ & $0(0)$ \\
\hline Full medication regimen polypharmacy review & $50(78.1)$ & $27(54)$ & $6(12)$ & $8(16)$ & $2(4)$ & $6(12)$ & $1(2)$ \\
\hline Targeted CKD renal medication review & $50(78.1)$ & $23(46)$ & $6(12)$ & $10(20)$ & $2(4)$ & $9(18)$ & $0(0)$ \\
\hline Targeted renal medication review: transplantation & $47(73.4)$ & $18(38.3)$ & 7 (14.9) & $6(12.8)$ & $2(4.3)$ & $\begin{array}{l}13 \\
(27.7)\end{array}$ & $1(2.1)$ \\
\hline Targeted renal medication review: vasculitis & $44(68.8)$ & $13(29.5)$ & $3(6.8)$ & $5(11.4)$ & $1(2.3)$ & $22(50)$ & $0(0)$ \\
\hline Targeted renal medication review: anemia & $42(65.6)$ & $15(37.5)$ & $6(14.3)$ & $9(21.4)$ & $1(2.4)$ & $\begin{array}{l}11 \\
(26.2)\end{array}$ & $0(0)$ \\
\hline Targeted renal medication review: hypertension & $42(65.6)$ & $20(47.6)$ & $5(11.9)$ & $4(9.5)$ & $2(4.8)$ & $\begin{array}{l}11 \\
(26.2)\end{array}$ & $0(0)$ \\
\hline Consulting inpatients with mineral bone disease & $49(76.6)$ & $19(38.8)$ & $6(12.2)$ & $11(22.4)$ & $2(4.1)$ & $\begin{array}{l}10 \\
(20.1)\end{array}$ & $1(2)$ \\
\hline Consulting inpatients with acute kidney injury & $49(76.6)$ & $23(46.9)$ & $7(14.3)$ & $6(12.2)$ & $3(6.1)$ & $\begin{array}{l}10 \\
(20.4)\end{array}$ & $0(0)$ \\
\hline Consulting inpatients with renal complication & $46(71.9)$ & $24(52.2)$ & $7(15.2)$ & 9 (19.6) & $0(0)$ & $6(13)$ & $0(0)$ \\
\hline $\begin{array}{l}\text { Consulting inpatients on hemodialysis or peritoneal } \\
\text { dialysis }\end{array}$ & $45(70.3)$ & $24(53.3)$ & $5(11.1)$ & $7(15.6)$ & $3(6.7)$ & $6(13.3)$ & $0(0)$ \\
\hline Medicines reconciliation & $57(89.1)$ & $34(59.6)$ & $15(26.3)$ & $3(5.3)$ & $2(3.5)$ & $2(3.5)$ & $1(1.8)$ \\
\hline Individual patient medication related education & $55(85.9)$ & $23(41.8)$ & $6(10.9)$ & $8(14.5)$ & $7(12.7)$ & $\begin{array}{l}10 \\
(18.2)\end{array}$ & $1(1.8)$ \\
\hline Meetings with multidisciplinary team & $52(81.3)$ & $11(21.2)$ & $4(7.7)$ & $13(25)$ & $12(23.1)$ & $\begin{array}{l}10 \\
(19.2)\end{array}$ & $2(3.8)$ \\
\hline Medical ward round with multidisciplinary team & $43(67.2)$ & $16(37.2)$ & 5 (11.6) & 9 (20.9) & $8(18.6)$ & $3(7)$ & $2(4.7)$ \\
\hline
\end{tabular}

Table 4

Characteristics of clinical pharmacy services you provide for OUTPATIENTS with CKD $(\mathrm{N}=64)$.

\begin{tabular}{|c|c|c|c|c|c|c|c|}
\hline \multirow[t]{3}{*}{ Area of care } & \multirow{3}{*}{$\begin{array}{l}\begin{array}{l}\text { Provision of } \\
\text { care }\end{array} \\
\text { Currently doing } \\
\mathrm{n}(\%)\end{array}$} & \multicolumn{6}{|c|}{ Frequency of 'Currently doing' care provision } \\
\hline & & \multirow{2}{*}{$\begin{array}{l}\text { Daily } \\
\text { Weekdays } \\
\text { n (\%) }\end{array}$} & \multirow{2}{*}{$\begin{array}{l}\text { Daily Weekdays and } \\
\text { Weekends } \\
\mathrm{n}(\%)\end{array}$} & \multirow{2}{*}{$\begin{array}{l}2-3 \mathrm{x} / \\
\text { week } \\
\mathrm{n}(\%)\end{array}$} & \multirow{2}{*}{$\begin{array}{l}\text { Once/ } \\
\text { week } \\
\mathrm{n}(\%)\end{array}$} & \multirow{2}{*}{$\begin{array}{l}\text { Ad hoc } \\
\mathrm{n}(\%)\end{array}$} & \multirow{2}{*}{$\begin{array}{l}\text { Missing } \\
\mathrm{n}(\%)\end{array}$} \\
\hline & & & & & & & \\
\hline General pharmaceutical care & $40(62.5)$ & $16(40)$ & $4(10)$ & $4(10)$ & $3(7.5)$ & $\begin{array}{l}13 \\
(32.5)\end{array}$ & $0(0)$ \\
\hline Meetings with multidisciplinary team & $41(64.1)$ & $3(7.3)$ & $2(4.9)$ & $10(24.4)$ & $13(31.7)$ & $9(22)$ & $1(2.4)$ \\
\hline Individual patient medication related education & $38(59.4)$ & $3(7.9)$ & $1(2.6)$ & $9(23.7)$ & $8(21.1)$ & $\begin{array}{l}16 \\
(42.1)\end{array}$ & $1(2.6)$ \\
\hline Pharmaceutical care for patients receiving dialysis & $38(59.4)$ & $13(34.2)$ & $3(7.9)$ & 5 (13.7) & $3(7.9)$ & $\begin{array}{l}13 \\
(34.2)\end{array}$ & $1(2.6)$ \\
\hline $\begin{array}{l}\text { Pharmaceutical care for patients at transplantation/ } \\
\text { follow-up }\end{array}$ & $37(57.8)$ & $13(35.1)$ & $2(5.4)$ & 7 (18.9) & $5(13.7)$ & $9(24.3)$ & $1(2.7)$ \\
\hline Medicines reconciliation & $31(48.4)$ & $8(25.8)$ & $6(19.4)$ & $7(22.6)$ & 4 (12.9) & $5(16.1)$ & $1(3.2)$ \\
\hline Full medication regimen poly-pharmacy review & $28(43.8)$ & 5 (17.9) & $1(3.6)$ & $8(28.6)$ & $3(10.7)$ & $\begin{array}{l}10 \\
(35.7)\end{array}$ & $1(3.6)$ \\
\hline Targeted renal medication review: transplantation & $29(45.3)$ & $7(24.1)$ & $1(3.4)$ & $6(20.7)$ & $5(17.2)$ & $\begin{array}{l}10 \\
(34.5)\end{array}$ & $0(0)$ \\
\hline Targeted CKD renal medication review & $27(42.2)$ & $1(3.7)$ & $1(3.7)$ & $5(18.5)$ & $4(14.8)$ & $\begin{array}{l}14 \\
(51.9)\end{array}$ & $1(3.7)$ \\
\hline Targeted renal medication review: vasculitis & $22(34.4)$ & $1(4.5)$ & $0(0)$ & $3(13.6)$ & $4(18.2)$ & $\begin{array}{l}14 \\
(63.6)\end{array}$ & $0(0)$ \\
\hline Targeted renal medication review: anemia & $21(32.8)$ & $1(4.8)$ & $2(9.5)$ & $2(9.5)$ & $7(33.3)$ & $9(42.9)$ & $0(0)$ \\
\hline Targeted renal medication review: hypertension & $16(25)$ & $1(6.3)$ & $1(6.3)$ & $2(12.5)$ & $2(12.5)$ & $9(56.3)$ & $1(6.3)$ \\
\hline $\begin{array}{l}\text { Consulting out-patients on hemodialysis or peritoneal } \\
\text { dialysis }\end{array}$ & $22(34.4)$ & $2(9.1)$ & $3(13.6)$ & $4(18.2)$ & $1(4.5)$ & $11(50)$ & $1(4.5)$ \\
\hline Consulting outpatients with renal complication & $20(31.3)$ & $1(5)$ & $1(5)$ & $7(35)$ & $2(10)$ & $9(45)$ & $0(0)$ \\
\hline Consulting outpatients with mineral bone disease & $17(26.6)$ & $1(5.9)$ & $1(5.9)$ & $2(11.8)$ & $5(29.4)$ & $8(47.1)$ & $0(0)$ \\
\hline Consulting outpatients with acute kidney injury & $9(14.1)$ & $1(11.1)$ & $0(0)$ & $1(11.1)$ & $1(11.1)$ & $6(66.7)$ & $0(0)$ \\
\hline
\end{tabular}

clinical pharmacy in CKD within the CFIR domain of 'intervention characteristics: evidence strength'.

The highest levels of agreement were received for the CFIR domain 'process of implementation' and specifically related to opinion leaders (social influences). Almost all agreed/strongly agreed with the statements, "the actions and views of renal specialists influence my practice" $(95.3 \%, \mathrm{n}=61)$ and, "the actions and views of other members of my profession influence my practice" $(89 \%, \mathrm{n}=57)$. 
Table 5

Additional roles undertaken by the pharmacist to support delivery of patient care $(\mathrm{N}=64)$.

\begin{tabular}{|c|c|c|c|c|}
\hline \multirow[t]{3}{*}{ Role } & \multicolumn{4}{|l|}{ Provision } \\
\hline & \multirow{2}{*}{$\begin{array}{l}\text { Currently } \\
\text { doing } \\
\mathrm{n}(\%)\end{array}$} & \multirow{2}{*}{$\begin{array}{l}\text { Planned } \\
\text { activity in } \\
\text { next } 12 \\
\text { months } \\
\mathrm{n}(\%)\end{array}$} & \multirow{2}{*}{$\begin{array}{l}\text { No } \\
\text { plans }\end{array}$} & \multirow{2}{*}{$\begin{array}{l}\text { Missing } \\
\mathrm{n}(\%)\end{array}$} \\
\hline & & & & \\
\hline $\begin{array}{l}\text { Audits/service evaluations/ } \\
\text { quality improvements }\end{array}$ & 46 (71.9) & $15(23.4)$ & $1(1.6)$ & $2(3.1)$ \\
\hline Care home support & $6(9.4)$ & $2(3.1)$ & $\begin{array}{l}52 \\
(81.3)\end{array}$ & $4(6.3)$ \\
\hline Academic research & $5(7.8)$ & $22(34.4)$ & $\begin{array}{l}33 \\
(51.6)\end{array}$ & $4(6.3)$ \\
\hline $\begin{array}{l}\text { Providing education/training } \\
\text { for other pharmacy staff }\end{array}$ & $58(90.6)$ & $5(7.8)$ & $0(0)$ & $1(1.6)$ \\
\hline $\begin{array}{l}\text { Providing education/training } \\
\text { for other healthcare } \\
\text { professionals }\end{array}$ & $54(84.4)$ & $6(9.4)$ & $2(3.1)$ & $2(3.1)$ \\
\hline $\begin{array}{l}\text { Providing education/training } \\
\text { for students }\end{array}$ & $52(81.3)$ & $6(9.4)$ & $5(7.8)$ & $1(1.6)$ \\
\hline $\begin{array}{l}\text { Providing education/training } \\
\text { for patient groups }\end{array}$ & $31(48.4)$ & $9(14.1)$ & $\begin{array}{l}21 \\
(32.8)\end{array}$ & $3(4.7)$ \\
\hline $\begin{array}{l}\text { Providing education/training } \\
\text { for carers }\end{array}$ & $29(45.3)$ & $6(9.4)$ & $\begin{array}{l}25 \\
(39.1)\end{array}$ & $4(6.3)$ \\
\hline $\begin{array}{l}\text { Providing mentoring for other } \\
\text { pharmacy staff }\end{array}$ & $56(87.5)$ & $5(7.8)$ & $2(3.1)$ & $1(1.6)$ \\
\hline $\begin{array}{l}\text { Providing mentoring for other } \\
\text { healthcare professionals }\end{array}$ & $32(50)$ & $7(10.9)$ & $\begin{array}{l}21 \\
(32.8)\end{array}$ & $4(6.3)$ \\
\hline $\begin{array}{l}\text { Involved in production of } \\
\text { national level guidelines, } \\
\text { strategy or policy }\end{array}$ & $12(18.7)$ & $13(20.3)$ & $\begin{array}{l}35 \\
(54.7)\end{array}$ & $4(6.3)$ \\
\hline $\begin{array}{l}\text { Involved in production of in- } \\
\text { house guidelines, strategy } \\
\text { or policy }\end{array}$ & $56(87.5)$ & $4(6.3)$ & $2(3.1)$ & $2(3.1)$ \\
\hline $\begin{array}{l}\text { Involved in drug and } \\
\text { therapeutics committee } \\
\text { submissions }\end{array}$ & $48(75)$ & 7 (10.9) & $\begin{array}{l}7 \\
(10.9)\end{array}$ & $2(3.1)$ \\
\hline $\begin{array}{l}\text { Participation in national } \\
\text { working groups e.g. UKRPG }\end{array}$ & $29(45.3)$ & $5(7.8)$ & $\begin{array}{l}27 \\
(42.2)\end{array}$ & $3(4.7)$ \\
\hline $\begin{array}{l}\text { High cost drugs- predict, plan } \\
\text { and monitor new } \\
\text { innovations in terms of } \\
\text { business care, funding and } \\
\text { reimbursement }\end{array}$ & $47(73.4)$ & $10(15.6)$ & $6(9.4)$ & $1(1.6)$ \\
\hline
\end{tabular}

Within the CFIR domain of 'inner setting: learning climate and process' there was clear disagreement with statements relating to having sufficient time to reflect on practice with more than half indicating they strongly disagree or disagree $(56.2 \%, \mathrm{n}=36)$ and the 'inner setting: available resources' statement on having sufficient cover for continuation of the clinical services provided when not in the department with $68.8 \%$ indicating they strongly disagree or disagree $(n=44)$.

The majority of respondents strongly agreed or agreed that they were burdened with having to provide other services taking them away from providing care $(65.6 \%, \mathrm{n}=42)$. Almost two thirds of respondents strongly disagreed or disagreed that they had sufficient administrative support to facilitate their practice $(65.6 \%, \mathrm{n}=42)$.

The statement associated with the CFIR domain of 'characteristics of individuals' indicates that in relation to 'self-efficacy', a high proportion of respondents strongly agreed or agreed that they are confident in their abilities in general and in working as part of the multidisciplinary team $(85.9 \%, \mathrm{n}=55)$.

There was also strong agreement with statements relating to the 'outer setting' domain of the CFIR with nearly $60 \%$ of respondents strongly agreeing or agreeing to the 'peer pressure' statement "I feel that colleagues in other organizations are ahead in implementing the role" $(59.4 \%, \mathrm{n}=38)$.

\section{Characteristics of prescribing practice}

Three quarters of the respondents $(75 \%, n=48)$ were qualified nonmedical prescribers and were currently actively prescribing. Most of them were practicing independent prescribing $(87.5 \%, n=42)$. More than half of the respondents had been registered with the United Kingdom General Pharmaceutical Council $(\mathrm{GPhC})$ as prescribers for between one and five years $(52.1 \%, \mathrm{n}=25)$. The respondents were prescribing in various areas related to CKD as shown in Fig. 1.

\section{Development and implementation of prescribing practice}

Table 7 provides responses to statements derived from CFIR on the development and implementation of prescribing practice relating to CKD. The highest level of agreement was reported within the CFIR domain of 'characteristics of individual: self-efficacy/personal attributes'. The majority of the participants $(93.7 \%, \mathrm{n}=45)$ indicated that they are competent to prescribe within the multidisciplinary team and $91.6 \%(n=44)$ agreed that they are competent in continuing the prescribing of medicines initiated by others. In relation to the domain of 'characteristics of individuals: other personal attributes' almost two thirds believed that patients would be treated more effectively if a pharmacist prescribes for them $(66.7 \%, \mathrm{n}=32)$, while $73 \%(\mathrm{n}=35)$ believed prescribing is more cost-effective if done by the pharmacist.

The highest levels of disagreement for statements related to the CFIR domain of 'process of implementation: construct of social influences', $(83.3 \%, \mathrm{n}=40)$ of the respondents disagreed about the fact that their prescribing is not fully supported by my multidisciplinary team and $(79.1 \%, \mathrm{n}=38)$ disagreed that their prescribing was not fully supported by their organization. The lowest level of agreement was for, "My prescribing is not fully supported by specialists" (strongly agree/agree $4.2 \%, \mathrm{n}=2$ ).

Through responses to statements in the CFIR domain 'intervention characteristics: evidence strength and quality' more than half of respondents strongly agreed or agreed that felt there was a need for more evidence for the benefits of pharmacist prescribing for patients with CKD $(56.2 \%, \mathrm{n}=27)$, There were mixed responses with statements relating to the 'outer setting' domain of the CFIR in relation to 'peer pressure'. Responses to the statement "I feel that colleagues in other organizations are ahead in implementing pharmacist prescribing in their practice" indicated $52 \%(\mathrm{n}=25)$ agreed with the statement and $29.2 \%(\mathrm{n}=14)$ disagreeing. Almost two-third $(64.6 \%, \mathrm{n}=31)$ of the respondents strongly agreed or agreed that 'other professional organizations influence their prescribing practice'.

Within the CFIR domain 'inner setting: available resources' for the statement on having 'sufficient time to prescribe' there was disparity in the responses among respondents. Around a third of the respondents $(37.5 \%, \mathrm{n}=18)$ strongly agreed or agreed, while $39.6 \%(\mathrm{n}=19)$ strongly disagreed or disagreed and the remainder $(18.7 \%, \mathrm{n}=9)$ neither agreed nor disagreed with the statement.

There was a similar response to the statement related to the sufficiency of administrative support to facilitate their prescribing' with $(37.5 \%, \mathrm{n}=18)$ in agreement and $(41.7 \%, \mathrm{n}=20)$ disagreeing with the statement.

\section{Discussion}

This study has provided evidence that the vast majority of UKRPG pharmacists practicing in CKD are independent prescribers, providing general pharmaceutical care to CKD patients in general and specifically to dialysis and kidney transplant patients. Respondents reported being confident in their own abilities and feeling comfortable in trying new ways of working. In relation to prescribing, most were confident in their abilities to initiate prescribing for individual patients within their areas of competence.

This work has been underpinned with theoretical approaches 
Table 6

Development and implementation of clinical pharmacy practice. Responses to items within each of the CFIR domains (Median in bold) $(\mathrm{N}=64)$.

\begin{tabular}{|c|c|c|c|c|c|}
\hline CFIR Domains and constructs & Statement & $\begin{array}{l}\text { Strongly } \\
\text { agree/Agree }\end{array}$ & $\begin{array}{l}\text { Neither agree } \\
\text { nor disagree }\end{array}$ & $\begin{array}{l}\text { Disagree/ } \\
\text { Strongly } \\
\text { disagree }\end{array}$ & Missing \\
\hline & & $\mathrm{n}(\%)$ & $\mathrm{n}(\%)$ & n (\%) & $\mathrm{n}(\%)$ \\
\hline $\begin{array}{l}\text { INTERVENTION CHARACTERISTICS: } \\
\text { EVIDENCE STRENGTH }\end{array}$ & $\begin{array}{l}\text { I feel there is a need for more evidence for the benefits of my } \\
\text { role }\end{array}$ & $39(61)$ & 14 (21.9) & $9(14.1)$ & $2(3.1)$ \\
\hline $\begin{array}{l}\text { INTERVENTION CHARACTERISTICS: } \\
\text { QUALITY/COST }\end{array}$ & $\begin{array}{l}\text { I feel that cost of service provision is a deterrent to the } \\
\text { development of my role }\end{array}$ & $45(70.3)$ & $8(12.5)$ & $10(15.6)$ & $1(1.6)$ \\
\hline CHARACTERISTICS OF INDIVIDUALS: SELF & I am confident in my abilities & 55 (85.9) & $6(9.3)$ & $2(3.2)$ & $1(1.6)$ \\
\hline EFFICACY/PERSONAL ATTRIBUTES & $\begin{array}{l}\text { I am confident in my ability as a member of the } \\
\text { multidisciplinary team }\end{array}$ & $55(85.9)$ & $5(7.8)$ & $2(3.2)$ & $2(3.2)$ \\
\hline \multirow[t]{2}{*}{ OUTER SETTING: PEER PRESSURE } & $\begin{array}{l}\text { I feel that colleagues in other organizations are ahead in } \\
\text { implementing the role }\end{array}$ & $38(59.4)$ & $16(25)$ & $8(12.5)$ & $2(3.2)$ \\
\hline & $\begin{array}{l}\text { Advice and guidance from professional organization such as } \\
\text { UKRPG influence how I practise in my role }\end{array}$ & $50(78.1)$ & $9(14.1)$ & $4(6.3)$ & $1(1.6)$ \\
\hline \multirow[t]{3}{*}{ INNER SETTING: GOALS/FEEDBACK } & I have clear goals for what I want to achieve when I practise & $49(76.5)$ & $12(18.7)$ & $2(3.2)$ & $1(1.6)$ \\
\hline & I have clear goals for developing clinical pharmacy services & $41(64.1)$ & $13(20.3)$ & $8(12.5)$ & $2(3.2)$ \\
\hline & I have clear goals relating to my CPD needs & $46(71.9)$ & $11(17.2)$ & $6(9.3)$ & $1(1.6)$ \\
\hline $\begin{array}{l}\text { INNER SETTING: AVAILABLE RESOURCES/ } \\
\text { ACCESS TO KNOWLEDGE \& INFORMATION }\end{array}$ & I feel I have sufficient time to practise in my role & $11(17.2)$ & $5(7.8)$ & $47(73.4)$ & $1(1.6)$ \\
\hline \multirow[t]{7}{*}{$\begin{array}{l}\text { INNER SETTING: AVAILABLE RESOURCES/ } \\
\text { ACCESS TO KNOWLEDGE \& INFORMATION }\end{array}$} & $\begin{array}{l}\text { I feel that I have sufficient cover for continuation of the } \\
\text { clinical services I provide when I am not in the department }\end{array}$ & $14(21.9)$ & $5(7.8)$ & $44(68.8)$ & 1 (1.6) \\
\hline & $\begin{array}{l}\text { I feel that I am burdened with having to provide other } \\
\text { services that take me away from providing care for patient } \\
\text { with CKD }\end{array}$ & $42(65.6)$ & $8(12.5)$ & $13(20.4)$ & $1(1.6)$ \\
\hline & $\begin{array}{l}\text { I feel I have sufficient administrative support to facilitate my } \\
\text { practice }\end{array}$ & $10(15.7)$ & 11 (17.2) & $42(65.6)$ & 1 (1.6) \\
\hline & $\begin{array}{l}\text { I feel I have adequate access to patient information (case } \\
\text { notes, lab data etc) to practise in my role }\end{array}$ & $59(92.2)$ & $2(3.2)$ & $2(3.2)$ & 1 (1.6) \\
\hline & $\begin{array}{l}\text { I have sufficient support from specialists to enable me to } \\
\text { practise in my role }\end{array}$ & $53(82.9)$ & $8(12.5)$ & $2(3.2)$ & $1(1.6)$ \\
\hline & $\begin{array}{l}\text { I feel I have adequate time to attend courses and conferences } \\
\text { for my development }\end{array}$ & $17(26.6)$ & $11(17.2)$ & $33(51.1)$ & 1 (1.6) \\
\hline & $\begin{array}{l}\text { I feel I have adequate access to funds to allow me to attend } \\
\text { courses and conferences to help development in my role }\end{array}$ & $13(20.3)$ & $11(17.2)$ & $39(61)$ & 1 (1.6) \\
\hline \multirow[t]{2}{*}{$\begin{array}{l}\text { INNER SETTING: LEARNING CLIMATE AND } \\
\text { PROCESS: REFLECTING \& EVALUATING }\end{array}$} & $\begin{array}{l}\text { I feel that my clinical knowledge is valued and used by the } \\
\text { multidisciplinary team }\end{array}$ & 57 (89) & $5(7.8)$ & 1 (1.6) & 1 (1.6) \\
\hline & $\begin{array}{l}\text { I am comfortable in my clinical pharmacy practice to try out } \\
\text { new methods of service delivery }\end{array}$ & $42(65.6)$ & $11(17.2)$ & 10 (15.7) & 1 (1.6) \\
\hline \multirow[t]{2}{*}{$\begin{array}{l}\text { INNER SETTING: LEARNING CLIMATE AND } \\
\text { PROCESS: REFLECTING \& EVALUATING }\end{array}$} & $\begin{array}{l}\text { I feel I have sufficient time to reflect and think about my } \\
\text { clinical pharmacy practice }\end{array}$ & $13(20.3)$ & 14 (21.9) & $36(56.2)$ & 1 (1.6) \\
\hline & $\begin{array}{l}\text { I have ways of monitoring the quality of my clinical } \\
\text { pharmacy practice caring for patients with CKD }\end{array}$ & $12(18.7)$ & 17 (26.6) & $34(53.1)$ & 1 (1.6) \\
\hline \multirow[t]{6}{*}{$\begin{array}{l}\text { PROCESS: OPINION LEADERS (SOCIAL } \\
\text { INFLUENCES) }\end{array}$} & $\begin{array}{l}\text { The actions and views of other members of my profession } \\
\text { influence my practice }\end{array}$ & 57 (89) & $4(6.3)$ & $2(3.2)$ & 1 (1.6) \\
\hline & $\begin{array}{l}\text { The actions and views of renal specialists influence my } \\
\text { practice }\end{array}$ & $61(95.3)$ & $2(3.2)$ & $0(0)$ & 1 (1.6) \\
\hline & $\begin{array}{l}\text { I feel my role as a clinical pharmacist is not fully supported } \\
\text { by my peers }\end{array}$ & $16(25)$ & $11(17.2)$ & $36(56.3)$ & 1 (1.6) \\
\hline & $\begin{array}{l}\text { I feel my role as clinical pharmacist for patients with CKD is } \\
\text { not fully supported by my multidisciplinary team }\end{array}$ & $9(14.1)$ & $6(9.3)$ & $48(75)$ & 1 (1.6) \\
\hline & $\begin{array}{l}\text { I feel my role as a clinical pharmacist for patients with CKD } \\
\text { is not fully supported by my organization }\end{array}$ & $17(26.6)$ & $13(20.3)$ & 33 (51.5) & 1 (1.6) \\
\hline & $\begin{array}{l}\text { I feel my role as a clinical pharmacist for patients with CKD } \\
\text { is not fully supported by specialists }\end{array}$ & $5(7.8)$ & $10(15.6)$ & $48(75)$ & 1 (1.6) \\
\hline $\begin{array}{l}\text { PROCESS: OPINION LEADERS (SOCIAL } \\
\text { INFLUENCES) }\end{array}$ & $\begin{array}{l}\text { The actions and views of other members of the multi- } \\
\text { disciplinary team influence my practice }\end{array}$ & 57 (89) & $5(7.8)$ & 1 (1.6) & 1 (1.6) \\
\hline
\end{tabular}

throughout its planning and execution. The use of CFIR has provided a framework that has enabled the research team to develop a comprehensive understanding of the facilitators and barriers to the implementation of clinical services in general and, in particular, new models of prescribing practice in CKD. Facilitators for the implementation of new services such as prescribing practice included; experience of service provision and confidence in their abilities (characteristics of individuals); having support from multidisciplinary team members (process); having clear goals for further development (inner setting) and support from professional organizations (outer setting). Barriers to implementing new models of practice included a lack of evidence for the benefit of new clinical pharmacy services in CKD. This was particularly true for the development of prescribing practice (intervention characteristics/evidence and quality). The lack of funding to support clinical pharmacy services was also considered a barrier to service development (inner setting/available resources). Many respondents felt burdened by having to provide 'core' clinical and other non-clinical services (inner setting/available resources).

Graham-Clarke et al. describe the facilitators and barriers to implementation of non-medical prescribing in a systematic review. It included 


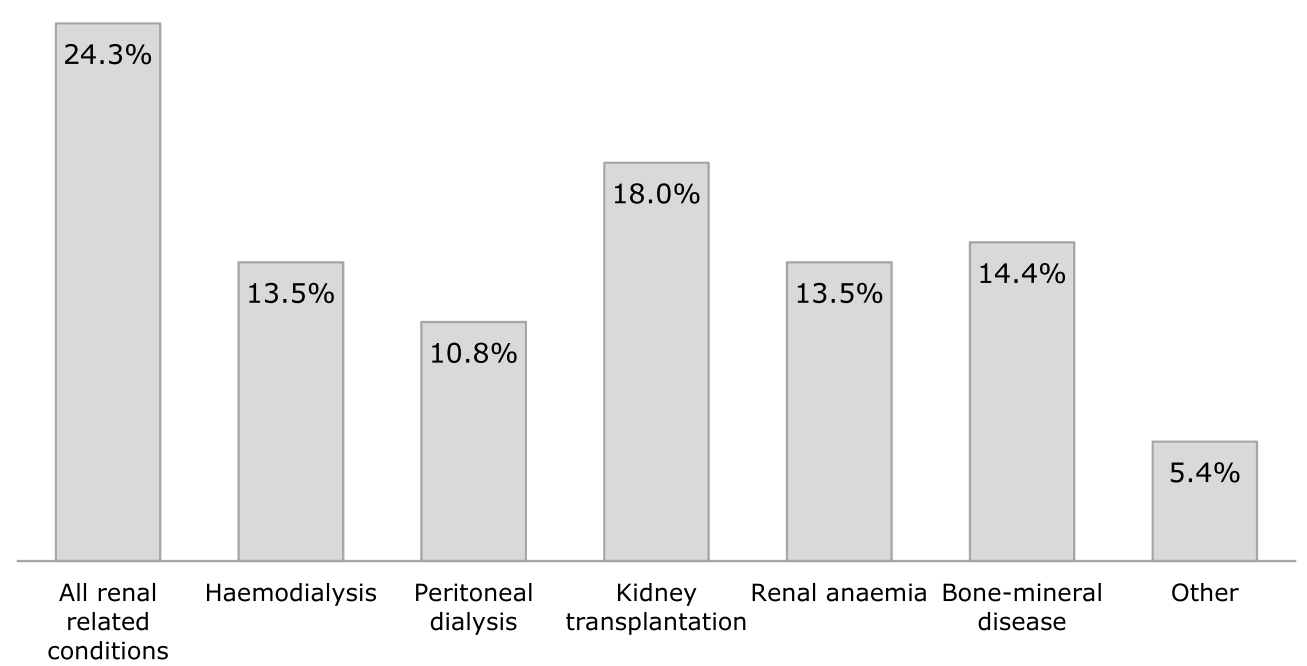

Fig. 1. Area(s) of prescribing relating to the care of patients with $\mathrm{CKD}(\mathrm{N}=48)$.

42 papers and reported on the complex interdependent interplay of themes that could act as facilitators or barriers depending on particular circumstances. ${ }^{23}$ Facilitators identified included trust, understanding and confidence of the multidisciplinary team in the non-medical prescribing role. These social influences are also reflected in the results of this present study where pharmacist respondents felt that they have the support of the multi-disciplinary team, their organization and specialists to prescribe. They also expressed high level of self-efficacy with many indicating that they felt confident and competent particularly in their prescribing practice. Graham-Clarke et al. also reported that cost and budget limitations were among the main barriers to nonmedical prescribing. ${ }^{23}$ In this present study respondents expressed a broad range of responses in relation to resource availability for aspects of prescribing practice such as having sufficient time to prescribe and having sufficient administrative support. There was, however, a clear desire to have more resources to ensure continuity of prescribing services during periods of staff absence. A majority of respondents also indicated a lack of resource to cover other services that take them away from the prescribing role. Given this, it is likely that structures and processes of care provision vary across different organizations resulting in operational differences and a differential impact of these factors on patient care.

While respondents, in this study, were practicing almost exclusively in secondary care, it should be noted that, there is potential for community pharmacists to contribute to CKD management. A study, published in 2014, reported that community pharmacists are willing to have more input to the care of patients with CKD. It noted that there is a need to increase awareness among patients to the availability of resources and services in the community. ${ }^{24} \mathrm{~A}$ recent study, in Scotland, reported that there is a growing pharmacy workforce in general medical practices for the delivery of clinical and prescribing services. ${ }^{25}$ There may be potential for involvement of this workforce in the shared care of patients with CKD. Al Hamarneh et al. reported that pharmacists in the community setting can contribute to improvements in the care of patient with CKD by providing clinical services such as; medication management, patient education, and prescribing. ${ }^{14}$

Some time ago the visionary UK National Renal Workforce Planning Group highlighted that pharmacist prescribing will impact on the level and type of services provided by pharmacists and that variations in levels of renal pharmacy service provision would be narrowed. ${ }^{26}$ It is therefore heartening that this survey shows that many respondents were active prescribers in CKD and providing a range of clinical services in a variety of settings. However, there is a need for further robust research in the area of nonmedical prescribing to add to the limited evidence base that shows it provides safe, effective and cost-effective care. ${ }^{10,15}$

In view of this, it is of some concern that few of the specialised renal pharmacists in this study were involved in any research. Previous studies have reported a variety of barriers to pharmacists engaging in research activities including; lack of time, availability of funding, lack of research knowledge and logistic issues. ${ }^{27}$ To enhance this strategies have been proposed. ${ }^{28-30}$ Collaboration of academics with professional organizations can be an attractive tool to enhance the development of a research culture, ethos and skill base in pharmacists. ${ }^{28,30}$ A UK survey of community pharmacies in London and Essex reported that $43 \%$ of respondents had participated in some form of pharmacy practice research, which indicates a willingness to engage. ${ }^{31}$ A recently published study on the views and experiences of practicing pharmacists to research reported that a minority of experienced secondary care pharmacists are involved in performing research based activities. However, again participants showed an interest in being involved in research. ${ }^{32}$

Specific barriers to the development of clinical and prescribing services reported in this study were time, resources, training and administrative support. These challenges are not unique to this study and have been reported repeatedly in the literature. ${ }^{9,10}$ A key facilitator to service development is provision of support through education and training. Studies suggest that clinical pharmacy education sessions had positive impacts on the management of CKD and that the cost expended on educational sessions are warranted to improve patient outcomes. ${ }^{33}$

One of the strengths to this study is that it is based on the use of a theoretical framework. Using theory within healthcare research is developing at pace and is leading to enhanced robustness and rigour. ${ }^{34}$ The UK Medical Research Council Framework for Developing and Evaluating Complex Interventions advocates the systematic use of appropriate theory to develop or evaluate an intervention or new services. ${ }^{35}$ Using the CFIR has resulted in findings that offer an original contribution to the evidence base around structures, processes, barriers and facilitators related to UK pharmacy service provision in CKD. Respondents were from all geographical areas of the UK and so, in this respect, the results are likely to reflect the breadth of UK practice and any difference in healthcare delivery in the devolved nations in the UK. Limitations include the fact that the response rate was around $50 \%$ and it could be considered that this may compromise the integrity of the findings. It should be noted, however, that such a response rate for a national online survey is commendable given the generally poor responses rate for such methods when applied to busy healthcare professionals. ${ }^{36}$ Part of the reason for a reduced number of responses may relate to the desire to carry out a theoretically based, robust and comprehensive study. As a result, the questionnaire may have been considered overly long and involved for some potential respondents. In addition, the research team aspired to be as economically and environmentally efficient through online dissemination of the questionnaire. 
Table 7

Development and implementation of prescribing practice. Responses to items within each of the CFIR domains (Median in bold) (N = 48).

\begin{tabular}{|c|c|c|c|c|c|}
\hline CFIR Domains and constructs & Statement & $\begin{array}{l}\text { Strongly } \\
\text { agree/Agree }\end{array}$ & $\begin{array}{l}\text { Neither agree } \\
\text { nor disagree }\end{array}$ & $\begin{array}{l}\text { Disagree/ } \\
\text { Strongly } \\
\text { disagree }\end{array}$ & Missing \\
\hline & & n (\%) & n (\%) & n (\%) & n (\%) \\
\hline \multirow[t]{3}{*}{$\begin{array}{l}\text { INTERVENTION CHARACTERISTICS: } \\
\text { EVIDENCE STRENGTH \& QUALITY/COST }\end{array}$} & $\begin{array}{l}\text { I feel there is a need for more evidence for the benefits of } \\
\text { pharmacist prescribing for patients with CKD }\end{array}$ & $27(56.2)$ & $12(25)$ & $7(14.6)$ & $2(4.2)$ \\
\hline & $\begin{array}{l}\text { I feel that cost of service provision is a deterrent to the } \\
\text { development of my prescribing practice }\end{array}$ & $25(52.1)$ & $9(18.7)$ & $12(25)$ & $2(4.2)$ \\
\hline & $\begin{array}{l}\text { I feel that the cost of some drugs used in CKD are a } \\
\text { deterrent to my prescribing }\end{array}$ & $6(12.5)$ & $10(20.8)$ & $30(62.5)$ & $2(4.2)$ \\
\hline \multirow[t]{4}{*}{$\begin{array}{l}\text { CHARACTERISTICS OF INDIVIDUALS: SELF } \\
\text { EFFICACY/PERSONAL ATTRIBUTES }\end{array}$} & $\begin{array}{l}\text { I am confident in my ability to initiate prescribing of } \\
\text { medicines for my patients }\end{array}$ & $38(79.2)$ & $5(10.4)$ & $3(6.3)$ & $2(4.2)$ \\
\hline & $\begin{array}{l}\text { I lack confidence in switching patients from one drug to } \\
\text { another when I prescribe }\end{array}$ & $5(10.4)$ & $12(25)$ & $29(60.5)$ & $2(4.2)$ \\
\hline & $\begin{array}{l}\text { I am confident in my ability to prescribe for patients with } \\
\text { CKD when they have been initiated on medicines by others }\end{array}$ & $41(85.4)$ & $3(6.3)$ & $2(4.2)$ & $2(4.2)$ \\
\hline & $\begin{array}{l}\text { I am confident in my ability to prescribe within the } \\
\text { multidisciplinary team }\end{array}$ & $43(89.6)$ & $3(6.3)$ & $0(0)$ & $2(4.2)$ \\
\hline \multirow[t]{4}{*}{$\begin{array}{l}\text { CHARACTERISTICS OF INDIVIDUALS: SELF } \\
\text { EFFICACY/PERSONAL ATTRIBUTES }\end{array}$} & $\begin{array}{l}\text { I lack competency to initiate prescribing of medicines for } \\
\text { my patients }\end{array}$ & $6(12.5)$ & $6(12.5)$ & $34(70.8)$ & $2(4.2)$ \\
\hline & $\begin{array}{l}\text { I am competent in continuing the prescribing of medicines } \\
\text { initiated by others }\end{array}$ & $44(91.6)$ & $1(2.1)$ & $1(2.1)$ & $2(4.2)$ \\
\hline & $\begin{array}{l}\text { I am competent to switch treatments (medicines) when I } \\
\text { prescribe for my patients }\end{array}$ & $42(87.5)$ & $1(2.1)$ & $3(6.3)$ & $2(4.2)$ \\
\hline & $\begin{array}{l}\text { I am competent to prescribe within the multidisciplinary } \\
\text { team }\end{array}$ & $45(93.7)$ & $1(2.1)$ & $0(0)$ & $2(4.2)$ \\
\hline \multirow[t]{9}{*}{$\begin{array}{l}\text { CHARACTERISTICS OF INDIVIDUALS: OTHER } \\
\text { PERSONAL ATTRIBUTES }\end{array}$} & $\begin{array}{l}\text { I feel anxious when initiating medicines for patients with } \\
\text { CKD }\end{array}$ & $12(25)$ & $12(25)$ & $22(45.9)$ & $2(4.2)$ \\
\hline & $\begin{array}{l}\text { I feel anxious when prescribing medicines which have been } \\
\text { initiated by others }\end{array}$ & $5(10.4)$ & $11(22.9)$ & $30(62.5)$ & $2(4.2)$ \\
\hline & $\begin{array}{l}\text { I get professional satisfaction when initiating the } \\
\text { prescribing for patients }\end{array}$ & $36(75)$ & $8(16.7)$ & $0(0)$ & $4(8.3)$ \\
\hline & $\begin{array}{l}\text { I get professional satisfaction when prescribing medicines } \\
\text { which have been initiated by others }\end{array}$ & $25(52.1)$ & $18(37.5)$ & $3(6.3)$ & $2(4.2)$ \\
\hline & $\begin{array}{l}\text { If I prescribe for patients with CKD, I believe that patients } \\
\text { will be treated more effectively }\end{array}$ & $32(66.7)$ & $11(22.9)$ & $3(6.3)$ & $2(4.2)$ \\
\hline & $\begin{array}{l}\text { If I prescribe for patients with CKD, I believe that patients } \\
\text { will have fewer adverse effects }\end{array}$ & $18(37.5)$ & $20(41.6)$ & $8(16.7)$ & $2(4.2)$ \\
\hline & $\begin{array}{l}\text { If I prescribe for patients with CKD, I believe that patients } \\
\text { will be treated more cost effectively }\end{array}$ & $35(73)$ & $9(18.7)$ & $1(2.1)$ & $3(6.3)$ \\
\hline & $\begin{array}{l}\text { If I do not prescribe for patients with CKD, I believe that } \\
\text { patients may come to harm }\end{array}$ & $14(29.2)$ & $11(22.9)$ & $21(43.7)$ & $2(4.2)$ \\
\hline & $\begin{array}{l}\text { If I have to switch medications in stabilised patients, I } \\
\text { believe that patient care may be compromised }\end{array}$ & $4(8.3)$ & $20(41.6)$ & $22(45.8)$ & $2(4.2)$ \\
\hline \multirow[t]{2}{*}{ OUTER SETTING: PEER PRESSURE } & $\begin{array}{l}\text { I feel that colleagues in other organizations are ahead in } \\
\text { implementing pharmacist prescribing in their practice }\end{array}$ & $25(52)$ & $7(14.6)$ & $14(29.2)$ & $2(4.2)$ \\
\hline & $\begin{array}{l}\text { Advice and guidance from professional organization such } \\
\text { as UKRPG influence my prescribing activity }\end{array}$ & $31(64.6)$ & $12(25)$ & $2(4.2)$ & $3(6.3)$ \\
\hline \multirow[t]{3}{*}{ INNER SETTING: GOALS/FEEDBACK } & $\begin{array}{l}\text { I have clear goals for what I want to achieve when I } \\
\text { prescribe for patients with CKD }\end{array}$ & $40(83.3)$ & $3(6.3)$ & $3(6.3)$ & $2(4.2)$ \\
\hline & $\begin{array}{l}\text { I have clear goals for developing services for patients with } \\
\text { CKD using my prescribing skills }\end{array}$ & $25(52)$ & $11(22.9)$ & 9 (18.7) & $3(6.3)$ \\
\hline & $\begin{array}{l}\text { I have clear goals relating to my CPD around prescribing for } \\
\text { patients with CKD }\end{array}$ & $31(64.5)$ & $8(16.7)$ & $7(14.6)$ & $2(4.2)$ \\
\hline INNER SETTING: AVAILABLE RESOURCES/ & I feel I have sufficient time to prescribe & $18(37.5)$ & $9(18.7)$ & $19(39.6)$ & $2(4.2)$ \\
\hline \multirow[t]{5}{*}{ ACCESS TO KNOWLEDGE \& INFORMATION } & $\begin{array}{l}\text { I feel that I have sufficient cover for continuation of the } \\
\text { prescribing services I provide when I am not in the } \\
\text { department }\end{array}$ & $12(25)$ & $1(2.1)$ & $33(68.7)$ & $2(4.2)$ \\
\hline & $\begin{array}{l}\text { I feel that I am burdened with having to provide other } \\
\text { services that take me away from prescribing }\end{array}$ & $31(64.6)$ & $2(4.2)$ & $13(27.1)$ & $2(4.2)$ \\
\hline & $\begin{array}{l}\text { Prescribing systems in my organization facilitate me in } \\
\text { prescribing }\end{array}$ & $24(50)$ & $12(25)$ & $10(20.8)$ & $2(4.2)$ \\
\hline & $\begin{array}{l}\text { I feel I have sufficient administrative support to facilitate } \\
\text { prescribing }\end{array}$ & $18(37.5)$ & $8(16.7)$ & $20(41.7)$ & $2(4.2)$ \\
\hline & $\begin{array}{l}\text { I feel I have adequate access to patient information (case } \\
\text { notes, lab data etc) to prescribe safely and effectively }\end{array}$ & $43(89.6)$ & $2(4.2)$ & $1(2.1)$ & $2(4.2)$ \\
\hline \multirow[t]{3}{*}{$\begin{array}{l}\text { INNER SETTING: AVAILABLE RESOURCES/ } \\
\text { ACCESS TO KNOWLEDGE \& INFORMATION }\end{array}$} & $\begin{array}{l}\text { I have sufficient support from expert advice and specialists } \\
\text { to enable me to prescribe safely and effectively }\end{array}$ & $41(85.4)$ & $4(8.3)$ & $0(0)$ & $3(6.3)$ \\
\hline & $\begin{array}{l}\text { I feel I have adequate time to attend courses and } \\
\text { conferences for my development as a prescriber }\end{array}$ & $16(33.4)$ & 7 (14.6) & $23(47.9)$ & $2(4.2)$ \\
\hline & & 8 (16.7) & 7 (14.6) & $31(64.6)$ & $2(4.2)$ \\
\hline
\end{tabular}


Table 7 (continued)

\begin{tabular}{|c|c|c|c|c|c|}
\hline CFIR Domains and constructs & Statement & $\begin{array}{l}\text { Strongly } \\
\text { agree/Agree }\end{array}$ & $\begin{array}{l}\text { Neither agree } \\
\text { nor disagree }\end{array}$ & $\begin{array}{l}\text { Disagree/ } \\
\text { Strongly } \\
\text { disagree }\end{array}$ & Missing \\
\hline & & $\mathrm{n}(\%)$ & $\mathrm{n}(\%)$ & $\mathrm{n}(\%)$ & $\mathrm{n}(\%)$ \\
\hline & $\begin{array}{l}\text { I feel I have adequate access to funds to allow me to attend } \\
\text { courses and conferences for my development as a } \\
\text { prescriber }\end{array}$ & & & & \\
\hline \multirow[t]{5}{*}{$\begin{array}{l}\text { INNER SETTING: LEARNING CLIMATE AND } \\
\text { PROCESS: REFLECTING \& EVALUATION }\end{array}$} & $\begin{array}{l}\text { I feel able to express my own prescribing development } \\
\text { needs and discuss these with colleagues }\end{array}$ & $33(68.7)$ & $7(14.6)$ & $6(12.5)$ & $2(4.2)$ \\
\hline & $\begin{array}{l}\text { I feel that my prescribing knowledge is valued and used by } \\
\text { the multidisciplinary team }\end{array}$ & $40(83.3)$ & $3(6.3)$ & $3(6.3)$ & $2(4.2)$ \\
\hline & $\begin{array}{l}\text { I am comfortable in my prescribing practice to try out new } \\
\text { methods of service delivery }\end{array}$ & $34(70.8)$ & $8(16.7)$ & $4(8.3)$ & $2(4.2)$ \\
\hline & $\begin{array}{l}\text { I feel I have sufficient time to reflect and think about my } \\
\text { prescribing practice }\end{array}$ & $16(33.4)$ & $10(20.8)$ & $19(39.6)$ & $2(4.2)$ \\
\hline & I have ways of monitoring the quality of my prescribing & $21(43.8)$ & $10(20.8)$ & $15(31.3)$ & $2(4.2)$ \\
\hline \multirow[t]{9}{*}{$\begin{array}{l}\text { PROCESS: OPINION LEADERS (SOCIAL } \\
\text { INFLUENCES) }\end{array}$} & $\begin{array}{l}\text { The actions and views of other members of the multi- } \\
\text { disciplinary team influence my prescribing activity }\end{array}$ & $40(83.3)$ & $5(10.4)$ & $1(2.1)$ & $2(4.2)$ \\
\hline & $\begin{array}{l}\text { The actions and views of other members of my profession } \\
\text { influence my prescribing activity }\end{array}$ & $36(75)$ & $8(16.7)$ & $2(4.2)$ & $2(4.2)$ \\
\hline & $\begin{array}{l}\text { The actions and views of renal specialists influence my } \\
\text { prescribing activity }\end{array}$ & $43(89.6)$ & $3(6.3)$ & $0(0)$ & $2(4.2)$ \\
\hline & My prescribing is not fully supported by my peers & $6(12.5)$ & $7(14.6)$ & $33(68.8)$ & $2(4.2)$ \\
\hline & $\begin{array}{l}\text { My prescribing is not fully supported by my } \\
\text { multidisciplinary team }\end{array}$ & $2(4.2)$ & $4(8.3)$ & $40(83.3)$ & $2(4.2)$ \\
\hline & My prescribing is not fully supported by my organization & $3(6.3)$ & $4(8.3)$ & $38(79.1)$ & $3(6.3)$ \\
\hline & My prescribing is not fully supported by specialists & $2(4.2)$ & $5(10.4)$ & $37(77.1)$ & $4(8.3)$ \\
\hline & $\begin{array}{l}\text { The structures and processes within my organization } \\
\text { influence my prescribing activity }\end{array}$ & 31 (64.6) & $8(16.7)$ & $7(14.6)$ & $2(4.2)$ \\
\hline & $\begin{array}{l}\text { Increased scrutiny of my prescribing by my organization is } \\
\text { an influence on my prescribing }\end{array}$ & $14(29.2)$ & $17(35.4)$ & $15(31.3)$ & $2(4.2)$ \\
\hline
\end{tabular}

Questionnaire design and survey method have been shown to have an impact on response rates and this may have been the case in this survey. ${ }^{37}$ This was a self-completion questionnaire and as such it was not possible to confirm or triangulate the validity of the responses. These could have been influenced by a number of biases including; non-response, social desirability and conformity, acquiescence and prestige bias. ${ }^{38}$ Furthermore, members of a professional network, like the UKRPG, may not be truly representative of a wider population of clinical pharmacists. Patients with CKD may also be managed by non-renal specialist pharmacists and their views on services to these patients may have added another dimension to the results. In addition, all participants were practicing in secondary care and so the results should obviously be viewed in this context. As noted above, clinical pharmacy services are developing rapidly in other sectors such as primary care in the UK and as such it would be appropriate to consider this in future studies.

Despite these limitations, it is evident that UK renal specialist pharmacists are highly involved in aspects of care of those with CKD, both in outpatient and inpatient settings. This includes general pharmaceutical care and more specialised care in dialysis and transplantation. A higher proportion of respondents provided inpatient services which is perhaps to be expected, given that the role of the specialist clinical pharmacist is more established in the hospital sector in the UK at present. However, there may be scope to extend this to outpatient settings and primary care. This may be achieved through further development of pharmacist prescribing practice arising from a policy related aspiration for all clinical pharmacists to be independent prescribers and have responsibility for their own case load of patients. ${ }_{40}^{39,}$

The Royal Pharmaceutical Society and UKRPG have produced a professional curriculum for renal expert professional practice. ${ }^{15}$ The statements within the curriculum provide descriptions of the domains and levels of competency for renal specialists to benchmark their practice. ${ }^{15}$ This may have facilitated the development of practice and have helped contribute to the high self-reported levels of confidence and competence. Such expert professional curricula could also be used to help describe and benchmark the requirements for structures, processes and outcomes of care in renal practice. Al Raiisi et al. have highlighted the lack of published detail relating to the structures and processes of practice in CKD. ${ }^{10}$ There is also a lack of agreement on what constitute appropriate outcome measures for studies exploring clinical pharmacy services in patients with CKD and therefore a lack of consistency of choice and use of outcomes in studies. This lack of detail greatly reduces the usefulness of the evidence generated about the nature and extent of the care. The consequence of this is that it cannot be easily replicated or the results pooled in synthesis and meta-analysis type analysis.

This is highly relevant since in this study respondents expressed a desire to develop and implement innovative services to improve patient outcomes. An example of such innovation includes the RCT by Ishani et al.' $s{ }^{41}$ on assessing the role of interprofessional team in CKD management using telehealth. This study showed that telehealth is a feasible care delivery strategy but more detailed information on the structures and processes of this model of care and clarity on the theoretical basis for the intervention still need to be provided. ${ }^{41}$ A more detailed evidence base for such services that is well founded in a theoretical basis and robustly researched and reported will enable the connection of evidence to the development of care provision. ${ }^{42,43}$

There are several potential avenues for further research. It is evident that there is a high proportion of pharmacist prescribers working CKD and healthcare policy is stimulating the development of nonmedical prescribing practice. In addition to the need for further high-quality outcomes-based research there is a need for qualitative research to allow a more in-depth exploration into the role of the pharmacist in prescribing for patients with CKD.

\section{Conclusion}

Results of this survey indicate high levels of clinical practice including wide-spread non-medical prescribing activity. This survey has captured detailed information on pharmacists' behavior and 
experiences in the care of patients with CKD. Through robust application of theoretical approaches using the CFIR it has also enabled the identification of barriers and facilitators for the development of clinical pharmacy and pharmacist prescribing practice. Lack of availability of resource to allow pharmacists to undertake additional non-core clinical roles could be considered a significant barrier to further development of clinical pharmacy practices including prescribing. There is also a lack of involvement in and skills base for research among respondents. Further work is planned using qualitative methods to explore these matters in more depth.

\section{CRediT authorship contribution statement}

F. Alraiisi: Conceptualization, Methodology, Investigation, Writing original draft, Writing - review \& editing, Project administration. D. Stewart: Conceptualization, Methodology, Investigation, Writing original draft, Writing - review \& editing, Visualization, Supervision. C. Ashley: Conceptualization, Methodology, Investigation, Writing - original draft, Writing - review \& editing. M. Fahmy: Conceptualization, Methodology, Writing - review \& editing, Visualization. H. Alnaamani: Formal analysis, Investigation, Software, Writing - review \& editing. S. Cunningham: Conceptualization, Methodology, Investigation, Writing - original draft, Writing - review \& editing, Visualization, Supervision.

\section{Declaration of competing interest}

The authors declare that they have no conflict of interests to disclose.

\section{Acknowledgments}

The researchers would like to thank the board members of the UK RPG, and special thanks to Mr. John Monkhouse for his continuous support throughout the data collection phase. Thank you for all the faculty members of the pharmacy school at Robert Gordon University who have helped in reviewing and testing the data collection tool.

\section{References}

1. KDIGO clinical practice guideline for the evaluation and Management of chronic kidney disease. [online] Belgium. The Int Soc Nephrol. 2013;3(1):1. https://kdigo. org/wp-content/uploads/2017/02/KDIGO_2012_CKD_GL.pdf. Accessed March 23, 2020. Accessed.

2. Hill NR, Fatoba ST, Oke JL, et al. Global prevalence of chronic kidney disease-a systematic review and meta-analysis. PloS One. 2016;11(7), e0158765. https://doi. org/10.1371/journal.pone.0158765. . Accessed March 23, 2020. Accessed.

3. Levey AS, Coresh J, Bolton K, et al. K/DOQI clinical practice guidelines for chronic kidney disease: evaluation, classification, and stratification. Am J Kidney Dis. 2002; 39(2 suppl 1).

4. Crockell YJ. Management of chronic kidney disease: an emphasis on delaying disease progression and treatment options. Formulary. 2012;47(6):228-238.

5. Damien P, Lanham HJ, Parthasarathy M, Shah NL. Assessing key cost drivers associated with caring for chronic kidney disease patients. BMC Health Serv Res. 2016;16(1):690.

6. Mechta Nielsen T, Frøjk Juhl M, Feldt-Rasmussen B, Thomsen T. Adherence to medication in patients with chronic kidney disease: a systematic review of qualitative research. Clinical Kidney Journal. 2017;11(4):513-527.

7. Dalton K, Byrne S. Role of the pharmacist in reducing healthcare costs: current insights. Integrated Pharm Res Pract. 2017;6:37.

8. Franklin BD, Van Mil JW. Defining clinical pharmacy and pharmaceutical care. Int $J$ Clin Pharm. 2005;27(3):137.

9. Salgado TM, Moles R, Benrimoj SI, Fernandez-Llimos F. Pharmacists' interventions in the management of patients with chronic kidney disease: a systematic review. Nephrol Dial Transplant. 2012;27(1):276-292.

10. Al Raiisi F, Stewart D, Fernandez-Llimos F, Salgado TM, Mohamed MF, Cunningham S. Clinical pharmacy practice in the care of Chronic Kidney Disease patients: a systematic review. Int J Clin Pharm. 2019;41(3):630-666.

11. Damschroder LJ, Aron DC, Keith RE, Kirsh SR, Alexander JA, Lowery JC. Fostering implementation of health services research findings into practice: a consolidated framework for advancing implementation science. Implement Sci. 2009;4(1):50.

12. Yamamoto T, Nakayama I, Kawakatsu Y, et al. Effects of pharmacist participation in chronic kidney disease (CKD) network and CKD manual distribution on drug-related kidney injury. Pharmacoepidemiol Drug Saf. 2019;28(6):887-896.
13. Yang H, Li L, Hu X, et al. Impact of pharmacist-led post-transplant medication management for kidney transplant recipients: a retrospective pre-and postintervention study. J Clin Pharm Therapeut. 2019;44(4):603-610.

14. Al Hamarneh YN, Tsuyuki RT, Jones CA, et al. Effectiveness of pharmacist interventions on cardiovascular risk in patients with CKD: a subgroup analysis of the randomized controlled RxEACH trial. Am J Kidney Dis. 2018;71(1):42-51.

15. Renal Expert Professional Practice Curriculum. Professional Curriculum to Support Members with the Knowledge, Skills, Experience and Behaviours to Advance in Their Practice; 2014. https://www.rpharms.com/LinkClick.aspx?fileticket=dUZncYAt 4MQ\%3D\&portalid=0/. Accessed March 23, 2020. Accessed.

16. Stewart D, MacLure K, George J. Educating nonmedical prescribers. Br J Clin Pharmacol. 2012;74(4):662-667.

17. Stewart D, Jebara T, Cunningham S, Awaisu A, Pallivalapila A, MacLure K. Future perspectives on nonmedical prescribing. Thera Adv Drug Safety. 2017;8(6):183-197.

18. Tonna AP, Stewart D, West B, McCaig D. Pharmacist prescribing in the UK-a literature review of current practice and research. J Clin Pharm Therapeut. 2007;32 (6):545-556.

19. Lundblad JP. A review and critique of Rogers' diffusion of innovation theory as it applies to organizations. Organ Dev J. 2003;21(4):50.

20. Safaeinili N, Brown-Johnson C, Shaw JG, Mahoney M, Winget M. CFIR simplified: pragmatic application of and adaptations to the Consolidated Framework for Implementation Research (CFIR) for evaluation of a patient-centered care transformation within a learning health system. Learn Health Syst. 2019;4(1), e10201.

21. Nakash RA, Hutton JL, Jørstad-Stein EC, Gates S, Lamb SE. Maximising response to postal questionnaires-a systematic review of randomised trials in health research. BMC Med Res Methodol. 2006;6(1):5.

22. Gale NK, Heath G, Cameron E, Rashid S, Redwood S. Using the framework method for the analysis of qualitative data in multi-disciplinary health research. BMC Med Res Methodol. 2013;13(1):117.

23. Graham-Clarke E, Rushton A, Noblet T, Marriott J. Facilitators and barriers to nonmedical prescribing-A systematic review and thematic synthesis. PloS One. 2018;13 (4), e0196471.

24. Zhu L, Fox A, Chan YC. Enhancing collaborative pharmaceutical care for patients with chronic kidney disease: survey of community pharmacists. Can J Hosp Pharm. 2014;67(4):268.

25. Stewart D, Maclure K, Newham R, et al. A Cross-Sectional Survey of the Pharmacy Workforce in General Practice in Scotland. Family Practice; 2019. https://doi.org/ 10.1093/fampra/cmz052. cmz052 . Accessed March 23, 2020. Accessed on.

26. The Renal Team A Multi-Professional Renal Workforce Plan for Adults and Children with Renal Disease Recommendations of the National Renal Workforce Planning Group; 2002. http://www.wales.nhs.uk/sites3/documents/434/Workforce.pdf. Accessed February 5, 2020. Accessed on.

27. Awaisu A, Alsalimy N. Pharmacists' involvement in and attitudes toward pharmacy practice research: a systematic review of the literature. Res Soc Adm Pharm. 2015;11 (6):725-748.

28. Armour C, Brillant M, Krass I. Pharmacists' views on involvement in pharmacy practice research: strategies for facilitating participation. Pharm Pract. 2007;5(2): 59-66.

29. Peterson GM, Jackson SL, Fitzmaurice KD, Gee PR. Attitudes of Australian pharmacists towards practice-based research. J Clin Pharm Therapeut. 2009;34(4): $397-405$.

30. Krass I. Ways to boost pharmacy practice research. Pharmaceut J. 2015;295(7883).

31. Rosenbloom K, Taylor K, Harding G. Community pharmacists' attitudes towards research. Int J Pharm Pract. 2000;8(2):103-110.

32. Stewart D, Cunningham S, Strath A, et al. A theoretically informed survey of the views and experiences of practicing pharmacists on research conduct, dissemination and translation. Res Soc Adm Pharm. 2018;15(11):1298-1308.

33. Nasution A, Sulaiman SS, Shafie AA. Cost-effectiveness of clinical pharmacy education on infection management among patients with chronic kidney disease in an Indonesian hospital. Value Health Region Issue. 2013;2(1):43-47.

34. Brazil K, Ozer E, Cloutier MM, Levine R, Stryer D. From theory to practice: improving the impact of health services research. BMC Health Serv Res. 2005;5(1):1.

35. Campbell M, Fitzpatrick R, Haines A, et al. Framework for design and evaluation of complex interventions to improve health. Br Med J. 2000;321(7262):694-696.

36. Cho YI, Johnson TP, VanGeest JB. Enhancing surveys of health care professionals: a meta-analysis of techniques to improve response. Eval Health Prof. 2013;36(3): 382-407.

37. Nulty DD. The adequacy of response rates to online and paper surveys: what can be done? Assess Eval High Educ. 2008;33(3):301-314.

38. Creswell JW. Research Design: Qualitative, Quantitative, and Mixed Methods Approaches. SAGE Publications, Inc; fifth ed. (January 2, 2018).

39. Scotland NH. Achieving Excellence in Pharmaceutical Care: A Strategy for Scotland. vol. 110. The Scottish Government; 2017. https://www.gov.scot/publications/achie ving-excellence-pharmaceutical-care-strategy-scotland/. Accessed March 23, 2020. Accessed on.

40. The Renal Team a Multi-Professional Renal Workforce Plan for Adults and Children with Renal Disease. Recommendations of the National Renal Workforce Planning Group; 2002. http://www.wales.nhs.uk/sites3/documents/434/Workforce.pdf. Accessed March 23, 2020. Accessed on. 
41. Ishani A, Christopher J, Palmer D, et al. Telehealth by an interprofessional team in patients with CKD: a randomized controlled trial. Am J Kidney Dis. 2016;68(1): $41-49$.

42. Donabedian A. Evaluating the quality of medical care. Milbank Q. 2005;83(4): 691-729.
43. Raleigh VS, Foot C. Getting the Measure of Quality. Opportunities and Challenges. London: King's Fund; 2010. https://www.kingsfund.org.uk/sites/default/files/Getti ng-the-measure-of-quality-Veena-Raleigh-Catherine-Foot-The-Kings-Fund-January2010.pdf. Accessed March 23, 2020. Accessed on. 